\title{
Peningkatan Kemampuan Menyimpulkan Teks Hasil Observasi Menggunakan Model Pembelajaran MEA (Means-Ends Analysis) Siswa Kelas VII-1 SMP Bina Agung Tanjung Gusta Tahun Pelajaran 2018/2019
}

\author{
Syahrizal Akbar \\ Anisa Ulfandari \\ Universitas Prima Indonesia \\ akbarsyahrizal@gmail.com
}

\begin{abstract}
ABSTRAK
Penelitian ini bertujuan untuk mengetahui peningkatan hasil Dalam Menyimpulkan Teks Hasil Observasi Dengan Menggunakan Model Pembelajaran Mea (Means-Ends Analysis) Pada Siswa Kelas VII-1 Smp Bina Agung Tanjung Gusta Tahun Pelajaran 2018/2019. Masalah yang mendasar adalah rendahnya kemampuan menyimpulkan siswa. Pendekatan penelitian ini mengunakan kualitatif deskriptif dalam bentuk PTK. Subjek dari penelitian ini adalah siswa dan Guru Bahasa Indonesia siswa kelas VII-1. Teknik pengumpulan data dengan cara tes, wawancara, dan observasi. Prosedur penelitian ini menggunakan design Kemmis Mc Taggart, yaitu perencanaan, pelaksanaan, observasi, dan refleksi. Hasil penelitian ini adalah adanya peningkatan hasil pembelajaran menyimpulkan teks hasil observasi menggunakan model pembelajaran MEA setelah melakukan 2 siklus dengan rincian peningkatan dari $50 \%$ yang tuntas menjadi $85 \%$.
\end{abstract}

\section{Kata kunci: Teks hasil observasi, MEA, PTK}

\section{PENDAHULUAN}

Keterampilan menulis menjadi satu

diantara standar kompetensi yang terbagi atas beberapa kompetensi dasar di dalam kemampuan berbahasa. Salah satu kompetensi dasarnya adalah pembelajaran menyimpulkan Teks Hasil Observasi. Melalui kegiatan menyimpulkan teks hasil observasi peserta didik diharapkan mampu menggunakan pikiran dan gagasan dalam bentuk tulisan tentang suatu peristiwa atau masalah yang telah diamati. Namun dalam kenyataan yang diperoleh berdasarkan hasil observasi dan wawancara peneliti dengan guru bahasa indonesia yang mengajar di sekolah tersebut, siswa kurang memahami dalam pembelajaran menyimpulkan isi teks hasil observasi. Hasil yang diperoleh di dalam pembelajaran ini tidak memenuhi standar yang telah ditetapkan. Nilai KKM yang ditetapkan sekolah adalah 70. Namun, hanya $25 \%$ siswa yang dapat memenuhi target yang telah di tetapkan. Artinya, masih ada $75 \%$ siswa yang nilainya belum memenuhi standar KKM karena hanya mendapatkan nilai rata rata 60 .

Maka pembelajaran memerlukan metode yang menarik untuk mendukung berlangsungnya proses pembelajaran. Dalam proses pembelajaran guru sangat berperan penting terhadap keberhasilan menyimpulkan teks hasil. Guru harus 
memotivasi peserta didik dalam proses pembelajaran, serta mampu memilih metode yang tepat untuk pembelajaran menyimpulkan teks hasil observasi agar peserta didik tidak jenuh dan merasa bosan. Masalah tersebut juga pernah diteliti oleh Ayu (2017) dalam skripsi yang berjudul Penerapan "Model.

Pembelajaran MEA (Means Ends Analysis) Untuk Meningkatkan Kemampuan Berpikir Kritis”. Penerapan model MEA (Means Ends Analysis) dengan hasil penelitian siklus I mencapai $75 \%$ dan pada siklus II 90\% terjadi peningkagtan sebesar 20\%. Hasil penelitian tersebut menunjukkkan bahwa model Means Ends Analysis mampu meningkatkan kemampuan berpikir kritis siswa.

\section{METODE PENELITIAN}

Penelitian ini dilaksanakan di SMP Bina Agung Medan pada kelas VII1 Tahun Pelajaran 2018/2019 kel. Tanjung Gusta, kec. Medan Helvetia. Penelitian ini dilaksanakan pada semester genap Tahun Pelajaran 2018/2019. Penelitian ini menggunakan penelitian tindakan kelas menurut Sugiyono (2014: 3) "Pendekatan penelitian merupakan cara ilmiah untuk mendapatkan data dengan tujuan dan kegunaan tertentu. Berdasarkan hal tersebut terdapat empat kata kunci yaitu, cara ilmiah, data, tujuan, kegunaan”. Menurut Arikunto (2013: 134) "Penelitian tindakan kelas termasuk penelitian kualitatif, karena menggali informasi lebih rinci”.

Subjek dalam penelitian ini adalah siswa kelas VII-1 SMP Bina Agung Medan Tahun Pelajaran 2018/2019 yang berjumlah 34 siswa. Dan objek dalam penelitian ini adalah upaya peningkatan kemampuan menyimpulkan teks hasil observasi dengan menggunakan model pembelajaran Means-Ends Analysis (MEA) pada sub pokok bahasan keterampilan menulis dikelas VII-1 SMP Bina Agung Tanjung Gusta Tahun Pelajaran 2018/2019.

Dalam penelitian ini data yang digunakan yaitu data siswa dan data yang diperoleh dari guru bahasa Indonesia yang mengajar dismp bina agung tanjung gusta. Sumber data diperoleh dari tempat penelitian yakni di kelas VII-1 SMP Bina Agung Tanjung Gusta yang berupa informasi dari guru dan siswa kelas VII-1 SMP Bina Agung Tanjung Gusta melalui hasil wawancara, hasil tes belajar siswa pada pokok pembahasan menyimpulkan teks hasil observasi mata pelajaran Bahasa Indonesia melalui model Means-Ends Analysis (MEA).

Teknik pengumpulan data yang digunakan, yaitu wawancara, observasi, tes, dan dokumentasi 


\section{HASIL DAN PEMBAHASAN}

Proses pembelajaran pada penelitian ini yang sudah dilaksanakan peneliti dengan menerapkan model Means-Ends Analysis (MEA) untuk memperbaiki kemampuan menyimpulkan teks hasil observasi pada siswa kelas VII-1 SMP Bina Agung Tanjung Gusta telah mendapatkan hasil penelitian dengan menyatakan bahwa kemampuan siswa dalam menyimpulkan hasil teks observasi yang telah diamati dapat meningkat. Hasil penelitian ini terlihat dari penilaian tes yang diberikan kepada siswa untuk dikerjakan di setiap tahap-tahap kegiatan pembelajaran yang telah dilakukan penelitian yaitu siklus I, dan siklus II.

Pelaksanaan pembelajaran menyimpulkan teks hasil observasi pada siklus I diberikan tes awal untuk mengetahui kemampuan awal pemahaman siswa terhadap materi pembelajaran menyimpulkan teks hasil observasi dengan menerapkan model pembelajaran MeansEnds Analysis (MEA). Adapun hasilnya, 8 siswa (20\%) yang lulus mendapatkan standar nilai KKM 70. Sedangkan siswa yang belum lulus mendapatkan nilai 70 ada 26 siswa (80\%).
Tabel 3.1 Rekapitulasi Peningkatan Hasil Nilai Tes Kemampuan Menyimpulkan Teks Hasil Observasi Pada Siswa di Kelas VII-1 Pada Siklus I dan Siklus

Dalam hal tersebut, peneliti pun

\begin{tabular}{cccc}
\hline Rentang Nilai & Siklus & Siklus & ket \\
& I & II & \\
\hline $\mathbf{9 0 - 1 0 0 \%}$ & - & 2 & T \\
\hline $\mathbf{8 0 - 8 9 \%}$ & 1 & 5 & T \\
\hline $\mathbf{7 0 - 7 9 \%}$ & 7 & 20 & T \\
\hline $\mathbf{6 0 - 6 9 \%}$ & 8 & 5 & TT \\
\hline $\mathbf{0 - 5 9 \%}$ & 17 & 2 & TT \\
\hline$\Sigma$ & 34 & 34 & Total \\
\hline Nilai Tertinggi & 85 & 90 & - \\
\hline Nilai Terendah & 35 & 40 & - \\
\hline Persentase & 23,52 & 79,41 & -
\end{tabular}

Ketuntasan Klasikal $\% \quad \%$

\begin{tabular}{llll}
\hline Persentase & Yang & 76,47 & 20,58
\end{tabular}

Tidak Tuntas $\% \quad \%$

melakukan perlakuan untuk memperbaiki situasi pembelajaran menyimpulkan teks hasil observasi yang terjadi di kelas VII-1 dengan melakukan tindakan pembelajaran yaitu memperbaiki penerapan Means-Ends Analysis (MEA) untuk menyimpulkan teks hasil observasi yang dilaksanakan pada siklus II. Dari kegiatan pembelajaran tersebut sudah dilaksanakan dan hasil pelaksanaannya telah ditemukan jawabannya bahwa penerapan Means-Ends Analysis (MEA) dapat meningkatkan menyimpulkan teks hasil observasi pada 
siswa kelas VII-1 SMP Bina Agung

Tanjung Gusta. Adapun bukti data peningkatan nilai hasil pembelajaran menyimpulkan teks hasil observasi siswa siklus I dan siklus II dari tes yang telah diberikan pada akhir proses pembelajaran di tiap siklusnya dapat dilihat dalam rangkuman hasil penilaian menyimpulkan teks hasil observasi pada tabel 4.3 berikut.

Pada proses pembelajaran siklus I dan siklus II yang telah dilaksanakan dengan menerapkan Means-Ends Analysis (MEA) perbaikan dari kondisi awal siswa agar dapat mencapai target KKM 70 dan KKK siswa $\geq 75 \%$. Adapun hasilnya pada kegiatan pembelajaran siklus I yang peneliti lakukan di kelas VII-1 siswa yang lulus mendapatkan standar KKM 70 hanya 8 siswa $23,52 \%$. Sedangkan siswa yang belum lulus mendapatkan nilai 70 ada 26 siswa 76,47\%. Pada proses siklus I indikator keberhasilan pada penilaian KKK siswa belum sesuai atau melampaui $\geq 75 \%$ sehingga dapat disimpulkan belum tercapai.
Melihat dari siklus I tersebut perlu dilakukan perbaikan dari permasalahan yang ada sehingga peneliti mengidentifikasi dan merencanakan perbaikannya dengan melakukan tindakan proses pembelajaran di siklus II agar pembelajaran menyimpulkan teks hasil observasi siswa dapat meningkat sesuai nilai KKM pelajaran Bahasa Indonesia yaitu 70. Proses pembelajaran siklus II pun masih menggunakan Means-Ends Analysis (MEA). Adapun hasil penelitian yang peneliti peroleh nilai siswa di siklus II yang mendapatkan nilai 70 mencapai 27 siswa 79.41\%.Sedangkan siswa yang belum lulus mendapatkan nilai 70 adalah 7 siswa $20.58 \%$.

Untuk memberikan gambaran yang jelas atas pencapaian hasil penelitian yang telah meningkat pada siklus I dan siklus II dari hasil tes dalam pembelajaran menyimpulkan teks hasil observasi dapat dilihat melalui diagram 4.4 sebagai berikut. 


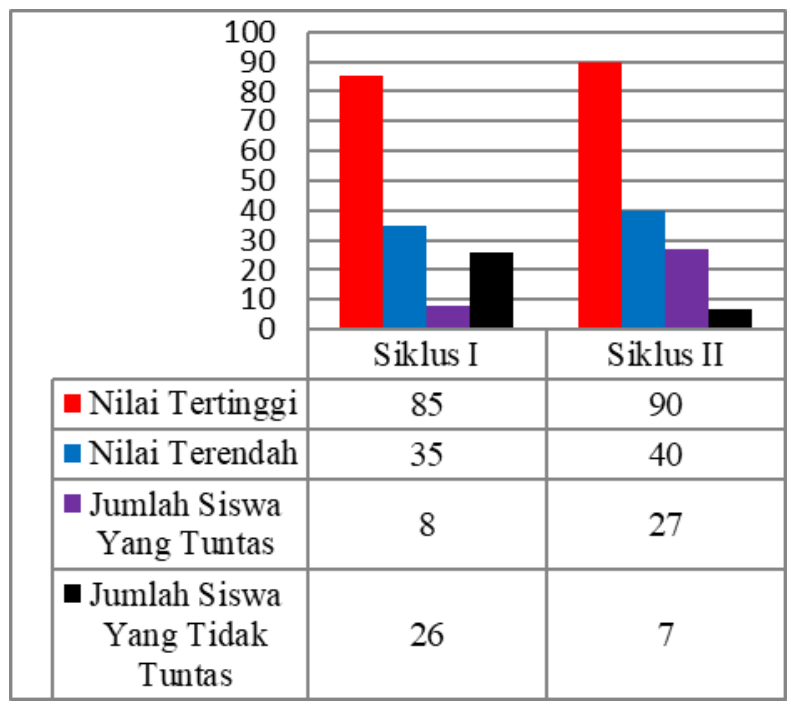

Diagram 3.1

Peningkatan Hasil Nilai Tes Siklus I dan Siklus II Menyimpulkan Teks Hasil Observasi pada SiswaKelas VII-1 SMP Bina Agung Tanjung Gusta Tahun Pelajaran 2018/2019

Berdasarkan penelitian yang telah dilakukan bahwa proses pembelajaran yang menerapkan Means-Ends Analysis (MEA) dapat meningkat kemampuan menyimpulkan teks laporan hasil observasi siswa kelas VII-1. Oleh karena itu, MeansEnds Analysis (MEA) pada mata pelajaran Bahasa Indonesia dapat berperan penting untuk meningkatkan kemampuan menyimpulkan teks hasil observasi siswa apalagi Means-Ends Analysis (MEA) dapat memberikan kesempatan kepada siswa untuk mengulang pembelajaran yang belum dipahaminya dengan berdiskusi dengan teman. Selain itu, Means-Ends Analysis (MEA) dapat melatih diri siswa untuk belajar mandiri sehingga pada saat siswa pembelajaran siswa sudah mempersiapkan diri mengobservasi benda yang akan di observasi, kemudian peneliti memberikan kesimpulan disetiap akhir yang bertujuan untuk melakukan pembelajaran lalu siswa dapat menjelaskan dengan bahasanya sendiri.

Oleh karena itu, proses pembelajaran Bahasa Indonesia yang menerapkan Means-Ends Analysis (MEA) dapat meningkatkan kemampuan menyimpulkan teks hasil observasi siswa kelas VII- SMP Bina Agung Tanjung Gusta.

Pembelajaran menyimpulkan teks hasil observasi merupakan kompetensi dasar Sekolah Menengah Pertama (SMP) yang harus dimiliki oleh siswa kelas VII-1. untuk mencapai kompetensi tersebut, 
pemilihan model dalam proses belajar mengajar yang menarik akan menentukan berhasil tidaknya tujuan yang ingin dicapai dalam pembelajaran tersebut. Guru bidang studi harus mampu memilih dan menerapkan model secara efektif yang berdampak hasil akhirnya mampu meningkatkan kemampuan menyimpulkan teks hasil observasi pada siswa.

Tahap tindakan yang telah dilakukan dalam penelitian ini adalah penerapan Means-Ends Analysis (MEA) untuk meningkatkan kemampuan menyimpulkan teks hasil observasi. Pemilihan model tersebut merupakan upaya untuk mengatasi permasalahan yang dihadapi guru dalam rangka meningkatkan keterampilan siswa dalam menyimpulkan teks observasi.

Means-Ends Analysis (MEA) menjadikan siswa lebih aktif, mandiri, dan antusias saat proses pembelajaran berlangsung. Siswa dituntut untuk berkonsentrasi penuh saat mengobservasi. Siswa lebih berperan aktif saat peneliti yang beraktivitas sebagai guru memberikan kesempatan kepada siswa untuk berdiskusi dengan teman sebangkunya dan pada saat penerapan Means-Ends Analysis (MEA) telah bergulir untuk proses penggalian pemahaman siswa dari apa yang telah dibacanya.

Model pembelajaran ini lebih menekankan peran siswa dalam pembelajaran, peneliti hanya berperan sebagai fasilitator dalam pembelajaran seperti mengondisikan keadaan pembelajaran yang sedang berlangsung di kelas.

Model pembelajaran pada proses pembelajaran menyimpulkan teks hasil observasi telah dilaksanakan melalui beberapa tahap tindakan pembelajaran sebanyak dua siklus. Masing-masing siklus dilakukan 4 x 40 menit dalam dua kali pertemuan yaitu 160 menit. Berdasarkan hasil observasi dan analisis dari siklus I dan II, pembelajaran menyimpulkan teks laporan hasil observasi dengan menerapkan model pembelajaran MeansEnds Analysis (MEA) mengalami peningkatan terhadap hasil pembelajaran menyimpulkan teks laporan hasil observasi siswa yang dilihat dari data hasil tes di akhir pembelajaran.

Dari keberhasilan dengan sudah meningkatnya kemampuan menyimpulkan teks laporan hasil observasi siswa kelas VII-1, namun berdasarkan hasil pengamatan peneliti dan guru dari lembaran observasi kegiatan guru dan kegiatan siswa pada siklus I dan siklus II terdapat beberapa aspek permasalahan yang telah diuraikan di tahap observasi sebelumnya. Lalu direncanakanlah proses perlakuan perbaikan dalam suatu tindakan di setiap siklusnya. Bukan hanya itu, pada kegiatan pembelajaran siswa saat 
pembelajaran dengan model pembelajaran Means-Ends Analysis (MEA) di siklus I hanya $23,52 \%$ siswa yang dapat dinyatakan memiliki tingkat penguasaan kemampuan menyimpulkan "tinggi".

Hal ini karena masih banyak siswa yang tidak mengikuti instruksi peneliti untuk membaca dan mempelajari ulang materi pembelajaran yang telah disampaikan, tidak semua siswa dapat memiliki konsentrasi yang tinggi, dan siswa belum terbiasa dalam menggunakan model pembelajaran Means-Ends Analysis (MEA) pada proses pembelajaran dengan baik dan benar sehingga masih ada siswa yang tidak memperdulikan penerapan model pembelajaran Means-Ends Analysis (MEA) saat pembelajaran berlangsung.

Pada proses pembelajaran di siklus II yang masih menerapkan model pembelajaran Means-Ends Analysis (MEA) sudah mengalami peningkatan. Hasil pembelajarannya mendapat nilai rata-rata keseluruhan siswa adalah 74.70 yang dapat dinyatakan memiliki tingkat penguasaan kemampuan menyimpulkan berkategori "tinggi". Hal ini karena sudah banyak siswa yang mau membaca dan mengikuti intruksi dari peneliti dalam proses pembelajaran keterampilan menulis dalam menyimpulkan teks laporan hasil observasi sehingga mendorong siswa untuk menulis dalam menyimpulkan teks laporan hasil observasi. mereka sudah terbiasa dan sangat antusias untuk melakukan pembelajaran dengan menggunakan model pembelajaran Means-Ends Analysis (MEA) sebagai penggali pemahaman siswa dari hal-hal yang telah dibacanya selama proses pembelajaran berlangsung sehingga terbukti terjadi peningkatan keterampilan menulis siswa.

Namun dari semuanya itu, guru dan peneliti menyatakan bahwa proses pembelajaran dalam menerapkan model pembelajaran Means-Ends Analysis (MEA) untuk meningkatkan kemampuan menyimpulkan teks laporan hasil observasi siswa kelas VII-1 SMP Bina Agung Tanjung Gusta sudah berjalan dengan baik dan lancar. Terlihat dari hasil penilaian di siklus I dan siklus II meningkat sesuai dengan Kriteria Ketuntasan Minimal (KKM) 70 dan nilai persentase Ketuntasan Klasikal (KKK) siswa dengan nilai $\geq 75 \%$. Dengan demikian, dapat disimpulkan bahwa berdasarkan rumusan masalah di Bab I dan hipotesis tindakan pada Bab II telah dinyatakan dan dipaparkan pada hasil penelitian di Bab IV ini, dalam penerapan model pembelajaran MEA (Means-Ends Analysis) dapat meningkatkan kemampuan menyimpulkan teks laporan hasil observasi siswa kelas VII-1 SMP Bina Agung Tanjung Gusta. Dalam hal tersebut dapat membantu guru bidang studi Bahasa 
Indonesia untuk lebih aktif lagi dalam mengelola kondisi kelas.

Terdapat beberapa aspek penilaian terhadap pembelajaran kemampuan menyimpulkan teks laporan hasil observasi pada siswa, yakni ketepatan isi tanggapan, kosakata, ekspresi, intonasi, gerak tubuh. Dari beberapa aspek penilaian tersebut meningkat pada siklus I dan siklus II. Adapun diantara aspek penilaian tidak meningkat yakni ketepatan isi tanggapan, kosakata dan ekspresi pada siklus I ke siklus II, karena pada saat siklus II banyak siswa yang tidak fokus akan pembelajaran karena adanya acara sekolah yang diadakan pada saat itu juga.

\section{SIMPULAN}

Peningkatan hasil pembelajaran kemampuan menyimpulkan teks laporan hasil observasi dengan menerapkan model Means-Ends Analysis (MEA) telah meningkat. Terbukti dari hasil penelitian nilai siklus I $23,52 \%$ dan terjadi peningkatan siklus II 79,41\%. Dan jumlah peningkatan yang di peroleh adalah $55,89 \%$.Oleh karena itu, model MeansEnds Analysis (MEA) pada bidang studi Bahasa Indonesia dengan sub pokok pembahasan materi pembelajaran menulis sangat berperan penting untuk meningkatkan kemampuan menyimpulkan teks laporan hasil observasi siswa dan mampu memberikan motivasi serta kesenangan siswa dalam proses pembelajaran kemampuan menyimpulkan teks laporan hasil observasi yang terkadang membuat siswa jenuh atau bosan sehingga siswa dapat lebih aktif dan lebih bersemangat dalam proses pembelajaran kemampuan menyimpulkan teks laporan hasil observasi di kelas VII-1 SMP Bina Agung Tanjung Gusta dengan konsep bermain sambil belajar.

\section{DAFTAR PUSTAKA}

Aqib, Zainal, dan dkk. 2009. Penelitian Tindakan Kelas. Bandung: CV Yrama Widya.

Arikunto, Suharsimi. 2013. Prosedur Penelitian: Suatu Pendekatan Praktik. Jakarta: Rineka Cipta.

Astuti, Sri 2016. "Meningkatkan Keterampilan Menyusun Teks Laporan Hasil Pengamatan”. Kendari

Hamdayana, Jumanta 2017. Model dan Metode Pembelajaran Kreatif dan Berkarakter. Bogor: Ghalia Indonesia.

Huda, Miftahul. 2014. Model-Model Pengajaran Dan Pembelajaran Isu-Isu Metodis Dan Paragdimatis. Yogyakarta: Pustaka Pelajar

Kosasih, E. 2014. Jenis-Jenis Teks Dalam Mata Pelajaran SMA/MA/SMK. Bandung: Yrama Widya..

Magdalena, theresia. 2017. "Pengaruh Model Pembelajaran Means-Ends Analysis Terhadap Kemampuan Pemecahan Masalah Matematika". 
Moleong, J Lexy. 2017. Metodologi Penelitian Kualitatif. Bandung: Remaja Rosdakarya

Nuryeni. 2015. "Kemampuan Menulis Teks Laporan Hasil Observasi”. Skripsi Medan: tidak terbit

Oktavia, 2017. "Model Pembelajaran Means-Ends Analysis (MEA) Untuk Meningkatkan Kemampuan Berpikir Kritis" Bandung : tidak diterbitkan
Trissanji, Sabrina .2016. "Peningkatan Keterampilan Menyusun Teks Laporan Hasil Observasi dengan Model Discovery Learning dan Metode Jelajah Alam Sekitar (JAS) pada Siswa Kelas VII-F SMP Negeri 1 Purbalingga".

Shoimin, Aris. 2016. Enam Puluh Delapan Model Pembelajaran Inovatif Dam KuriKulum 2013. Depok: Ar-Ruzz Media

Sugiyono. 2017. Metode Penelitian Kuantitatif, Kualitatif, Dan R\&D. Bandung: Alfabeta 